\title{
Spatial distribution and temporal variation of microcrustaceans assembly (Cladocera and Copepoda) in different compartments of a reservoir in the brazilian semiarid region
}

\author{
Distribuição espacial e variação temporal da assembleia de microcrustáceos \\ (Cladocera e Copepoda) em diferentes compartimentos de um reservatório no \\ semiárido brasileiro
}

Josiane Souza Santos ${ }^{1 *}$, Nadson Ressyé Simóes ${ }^{2}$ and Sérgio Luiz Sonoda ${ }^{3}$

${ }^{1}$ Programa de Pós-graduaçáo em Ecologia de Sistemas Aquáticos Tropicais, Universidade Estadual de Santa Cruz - UESC, Campus Prof. Soane Nazaré de Andrade, Rodovia Jorge Amado, Km 16, CEP 45662-900, Ilhéus, BA, Brasil

${ }^{2}$ Centro de Formação em Ciências Ambientais, Universidade Federal do Sul da Bahia - UFSB, Rodovia Porto Seguro-Eunápolis, BR 367, Km 10, CEP 45810-000, Porto Seguro, BA, Brasil

${ }^{3}$ Departamento de Ciências Biológicas, Universidade Estadual do Sudoeste da Bahia - UESB, Campus Jequié, Avenida José Moreira Sobrinho, s/n, Bairro Jequiezinho, CEP 45206-190, Jequié, BA, Brasil

*e-mail: josysouzabio@gmail.com

Cite as: Santos, J.S., Simões, N.R. and Sonoda, S.L. Spatial distribution and temporal variation of microcrustaceans assembly (Cladocera and Copepoda) in different compartments of a reservoir in the brazilian semiarid region. Acta Limnologica Brasiliensia, 2018, vol. 30, e108.

\begin{abstract}
Aim: The objective of this study was to investigate the spatial and temporal variation of microcrustacean assemblages of a reservoir in the Brazilian semiarid region. Methods: Physical and chemical water variables and samples of microcrustaceans were collected at eight sites of the reservoir between July 2013 and November 2014, in a total of seven campaigns. For this study, the reservoir was categorized in two compartments: lateral and central. Results: Limnological variables showed significant temporal variation (PERMANOVA, Pseudo-F $=19.51, \mathrm{p}=0.001$ ). Higher turbidity values and suspended solids were observed in the rainiest months, while during the dry months, we measured higher values of transparency, dissolved oxygen, and chlorophyll-a. It was not found significant spatial variation of limnological variables (PERMANOVA, Pseudo-F = 0.96; $\mathrm{p}=0.394$ ). During the study period, ten species were recorded: four Cladocera (Ceriodaphnia cornuta, Daphnia gessneri, Diaphanosoma birgei and Diaphanosoma spinulosum) three Copepoda Calanoida (Argyrodiaptomus azevedoi, Notodiaptomus cearensis and Notodiaptomus iheringi) and three Copepoda Cyclopoida (Macrocyclops albidus, Thermocyclops minutus and Thermocyclops decipiens). The microcrustacean assemblages showed significant temporal variation (PERMANOVA, Pseudo-F $=4.34 ; p=0.001$ ) as well as significant spatial variation (PERMANOVA, Pseudo-F = 9.46; $p=0.001$ ). The highest values of abundance and richness were observed in the lateral compartment, this result is mainly related to the presence of aquatic macrophytes in this region, because the analysis of partial RDA indicated that limnological variables explained only $11 \%$ of this variation (Pseudo-F $=2.08, p=0.001$ ). Conclusions: The results suggest that the seasonality of the semiarid is an important factor in the temporal dynamics of the limnological variables, while the aquatic macrophytes play an important role in the spatial distribution of the microcrustacean assembly.
\end{abstract}

Keywords: seasonality; zooplankton; limnology; Rio de Contas basin; Northeastern Brazil. 
Resumo: Objetivo: $\mathrm{O}$ objetivo deste estudo foi investigar a variaçấo espacial e temporal da assembleia de microcrustáceos de um reservatório no semiárido brasileiro. Métodos: As variáveis físicas e químicas da água e amostras de microcrustáceos foram coletadas em oito locais do reservatório entre julho de 2013 e novembro de 2014, num total de sete campanhas. Para este estudo, o reservatório foi categorizado em dois compartimentos: lateral e central. Resultados: As variáveis limnológicas apresentaram variação temporal significativa (PERMANOVA, Pseudo- $F=19,51, p=0,001$ ). Valores de turbidez mais altos e sólidos em suspensão foram observados nos meses mais chuvosos, enquanto nos meses secos foram medidos os valores mais elevados de transparência, oxigênio dissolvido e clorofila- $a$. Não houve variação espacial significativa das variáveis limnológicas (PERMANOVA, Pseudo-F $=0,96 ; \mathrm{p}=0,394)$. Durante o período de estudo, foram registradas dez espécies: quatro Cladocera (Ceriodaphnia cornuta, Daphnia gessneri, Diaphanosoma birgei e Diaphanosoma spinulosum), três Copepoda Calanoida (Argyrodiaptomus azevedoi, Notodiaptomus cearensis e Notodiaptomus iheringi) e três Copepoda Cyclopoida (Macrocyclops albidus, Thermocyclops minutus e Thermocyclops decipiens). A assembleia de microcrustáceos apresentou variação temporal (PERMANOVA, Pseudo-F = 4,34; $\mathrm{p}=0,001)$ e variação espacial significativa (PERMANOVA, Pseudo- $\mathrm{F}=9,46 ; \mathrm{p}=0,001$ ). Os maiores valores de abundância e riqueza foram observados no compartimento lateral, este resultado pode esta relacionado principalmente a presença de macrófitas aquáticas nesta regiáo, pois, a análise da RDA parcial indicou que as variáveis limnológicas explicaram apenas $11 \%$ desta variação (Pseudo- $\mathrm{F}=2,08$; $\mathrm{p}$ $=0,001)$. Conclusóes: Os resultados sugerem que a sazonalidade do semiárido é um fator importante na dinâmica temporal das variáveis limnológicas, enquanto as macrófitas aquáticas desempenham papel importante na distribuição espacial da assembleia de microcrustáceos.

Palavras-chave: sazonalidade; zooplâncton; limnologia; bacia do Rio de Contas; Nordeste do Brasil.

\section{Introduction}

In semi-arid regions, the irregularity of rainfall and high evaporation rates cause the loss of surface water, resulting in an intermittent hydric landscape and thus causing problems for water supply. Such water scarcity increases the needs to construct more reservoirs for water storage (Thornton \& Rast, 1993). Fauna and flora in these reservoirs are influenced mainly by aspects related to eutrophication and productivity (nutrient, chlorophyll-a, transparency, and electric water conductivity) (Simōes et al., 2015; Pinel-Alloul \& Mimouni, 2013; Pinto-Coelho et al., 2005), which naturally vary depending on drainage basin or cultural eutrophication processes. Reservoirs are favorable environments for the development of zooplankton (Rocha et al., 1999), because they have different compartments. Each compartment is subject to changes in physical and chemical water properties, gradients of extension and depth, leading to the emergence of new micro-habitats with a set of characteristics responsible for variations in density, species composition, and reproductive rates of organisms (Baxter, 1977; Panarelli et al., 2003; Tundisi, 2006). The presence of aquatic macrophytes in reservoirs is another factor that contributes to the heterogeneity of the environment, because supports a diversified invertebrate fauna that plays an important role in energy transfer and nutrient cycling in aquatic food webs (Junk \& Robertson, 1997).
These variations are the result of the responses to the forces of climate and effects produced by the management of water levels in the lake (Brito et al., 2011; Perbiche-Neves \& Nogueira, 2013). Thus, the compartments in the reservoir are not static, but a result of the combined effects of multiple gradients and may expand and contract depending on the flow and operation of the reservoir to form a dynamic environment (Kimmel et al., 1990; Bonecker et al., 2001; Nogueira, 2001). Zooplankton, for instance, has spatial and temporal variations related to biological, physical and chemical gradients which are promoted not only along the longitudinal axis, produced by transition region from river to lake (Marzolf, 1990), but also by differences in system morphometric of the reservoir (Espindola et al., 2000).

The characterization of the zooplankton community and its spatial distribution provide important data for the study of water bodies, allowing a wider knowledge of these environments and therefore enabling the establishment of adequate monitoring and management programs. Studies have shown the influence of the spatial partitioning of reservoirs on the zooplankton community and could demonstrate the importance of spatial and temporal components in these different regions (Betsill \& Van Den Avyle, 1994; Nogueira, 2001; Bernot et al., 2004). Zooplankton plays an important role in the energy flow between primary producers and consumers from higher trophic levels and is responsible for secondary 
productivity, transport, and regeneration of nutrients. In addition, zooplankton organisms have a short life cycle, high reproductive rates, and rapid development that allow immediate responses to environmental changes (Newel \& Newel, 1963). Thus, the study of the plankton community and a limnological analysis of the Barragem de Pedra reservoir contribute to the knowledge of aquatic biodiversity and can improve monitoring of policies and environmental management throughout this reservoir which is used for urban water supply.

In this study, we analyzed the importance of the local limnological conditions to microcrustacean richness, abundance, and evenness. We predict that microcrustacean assemblages show structural changes according to temporal and spatial environmental variations. To test that, this study characterized the reservoir based on physical and chemical variables; analyzed the temporal and spatial variation of microcrustacean assemblages, and verified whether these variations are related to the physical, chemical, and biological characteristics of the water.

\section{Material and Methods}

This study was carried out at the Barragem de Pedra reservoir, located in the state of Bahia in a semiarid region in Brazil. The reservoir (hydroelectric power plant) was constructed in 1967 in the middle-lower reaches of the Contas River and covers an area of $101 \mathrm{~km}^{2}$, with a storage capacity of $1,640 \mathrm{hm}^{3}$. Over the years, various activities have been carried out in the reservoir, such as aquaculture, irrigation, recreation, and currently the resourcing of water for the town of Jequié City, which had an estimated population of 161,528 (IBGE, 2016) inhabitants in 2015. The reservoir is surrounded by vegetation types of the Caatinga; according to the Köppen classification, the climate is Aw with a dry season from May to October and a rainy season from November to April.

Data were collected at eight points (Figure 1) from July 2013 to November 2014 every two months. Two compartments were considered: the lateral compartment consisted of P1, P2, P4, and $\mathrm{P} 5$ and the central compartment of $\mathrm{P} 3, \mathrm{P} 6, \mathrm{P} 7$, and P8. The points forming the lateral compartment were characterized by presenting macrophytes of the genus Egeria in all campaigns and by a shallower depth (7.3-13.4 m), while the points of the central compartment are deepest (15.3-19.6 m) (Table 1).

A multiparameter probe (HORIBA U 52) was used to measure temperature, $\mathrm{pH}$, conductivity, turbidity, and dissolved oxygen. Vertical profiles were performed with measurements every $0.5 \mathrm{~m}$ to a depth of $5.0 \mathrm{~m}$ and from there every $1 \mathrm{~m}$ to
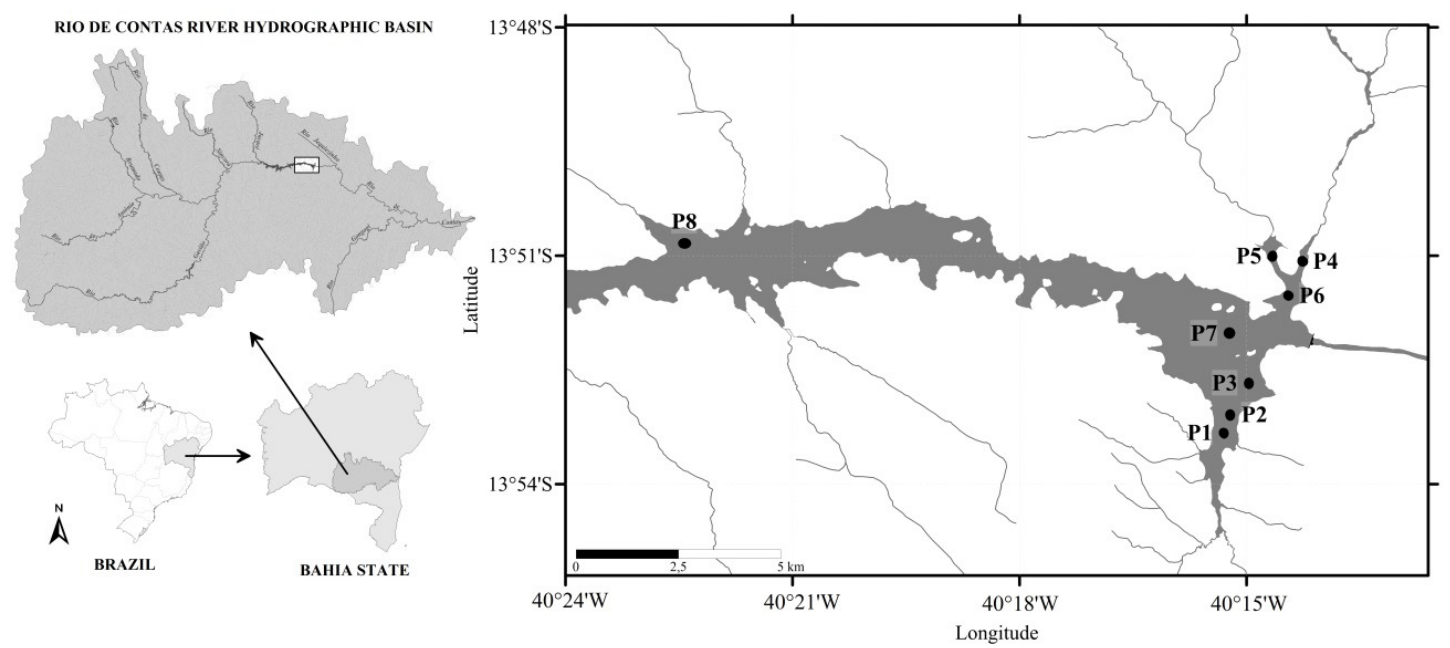

Figure 1. River basin of Rio de Contas and sampling sites in the reservoir Barragem da Pedra, Jequié, Bahia. P1, P2, P4, and P5 are sites in the lateral compartment while P3, P6, P7, and P8 are located in the central compartment.

Table 1. Mean depth $(\mathrm{m})$ ( \pm standard deviation) of the compartments sampled in the reservoir Barragem da Pedra between July 2013 and November 2014.

\begin{tabular}{lrrrcccc}
\hline & July & September & January & March & May & September & November \\
& $\mathbf{2 0 1 3}$ & $\mathbf{2 0 1 3}$ & $\mathbf{2 0 1 4}$ & $\mathbf{2 0 1 4}$ & $\mathbf{2 0 1 4}$ & $\mathbf{2 0 1 4}$ & $\mathbf{2 0 1 4}$ \\
\hline Central compartment & $17.5 \pm 5.5$ & $15.3 \pm 5.4$ & $19.6 \pm 5.3$ & $18.3 \pm 5.4$ & $16.0 \pm 5.6$ & $15.5 \pm 5.5$ & $17.6 \pm 6.1$ \\
Lateral compartment & $7.9 \pm 1.8$ & $7.3 \pm 2.8$ & $11.0 \pm 3.0$ & $12.7 \pm 3.3$ & $12.0 \pm 4.0$ & $11.0 \pm 3.5$ & $13.4 \pm 2.9$ \\
\hline
\end{tabular}


the bottom. Water transparency was estimated using a Secchi disk. At each point, water samples were collected for determination of total alkalinity (Mackereth et al., 1978), total suspended solids (Teixeira \& Kutner, 1962), and chlorophyll-a (Golterman et al., 1978).

Samples for qualitative and quantitative zooplankton analysis were collected using a conical net with a mesh size of $68 \mu \mathrm{m}$. For both analyzes, it was performed vertical bottom trawls to the surface at each sampled point; the filtered volumes ranged between 212 (minimum) and 1696 (maximum) liters. The obtained samples were fixed in formaldehyde buffered with $4 \%$ end concentration.

Zooplankton identification was carried out with the aid of a stereoscopic microscope, an optical microscope, and specialized literature (ElmoorLoureiro, 1997; Matsumura-Tundisi, 1986; Reid, 1985). Juveniles of copepods (nauplii and copepodids) were identified and counted to the level of order. Zooplankton was counted in an acrylic board with checkered background; counting was accomplished by removing aliquots of $10 \mathrm{ml}$ of the homogenized sample up to at least 200 individuals of the most abundant species, while for rare species, organisms were quantified in their entirety.

\subsection{Data analysis}

The physical and chemical features were analyzed using descriptive methods (mean, standard deviation) to characterize the sampled compartments. These variables were then used in a Principal Components Analysis (PCA) for environmental characterization of the reservoir. The following variables were considered: temperature, $\mathrm{pH}$, dissolved oxygen, conductivity, transparency, alkalinity, chlorophyll-a, total suspended solids, and organic and inorganic fractions. For this analysis, it was used a correlation matrix and the axes were selected according to the criteria of Broken Stick model (Legendre \& Legendre, 1998). One analysis of multivariate permutation variance (PERMANOVA: Permutational Multivariate Analysis of Variance procedure) was used to test the influence of temporal and spatial variations on the limnological variables.

It was calculated the zooplankton community attributes richness, abundance, and evenness for each sampled month, taking into account the central and lateral compartments (Krebs, 1998; Magurran, 2013). To verify if there were statistically significant spatial and temporal differences, these metrics were tested using ANOVA with repeated measures to control temporal pseudoreplication. Prior to analysis, data were transformed $(\log \mathrm{x}+1)$ to meet the assumptions of normality and homoscedasticity. The influence of temporal and spatial variation on the community structure was tested with PERMANOVA. Non-parametric Mann-Whitney test was used to verify differences and compare juvenile copepod abundances between the compartments, as the assumptions of normality and homoscedasticity were not achieved.

To check the spatial and temporal variation of the assemblages, it was also used non-metric multidimensional scaling (NMDS: non-metric multidimensional scaling), adopting as measure of dissimilarity the Bray-Curtis index. The distortion of the resolution in a two-dimension ordination is expressed by the value of $S$ (called stress). The closer to zero, the better the fit between the original distance of the objects and the obtained configuration (Legendre \& Legendre, 1998). For the species-environment analysis, it was ran a Partial Redundancy Analysis (pRDA) using as dependent variables an array of microcrustacean species and as explanatory variables the abiotic data (total alkalinity, chlorophyll, $\mathrm{pH}$, temperature, turbidity, and Secchi transparency). The pRDA consists in the realization of an RDA, but removing the effect of covariates. The selection of variables was performed using a forward selection procedure which performs permutations in order to select the best model for explaining the variation in the data. In this case, the effect was removed from the covariate time (months) and for the variable space (central and lateral compartment). The effect of time was removed because it is one of the main factors that interfere with aquatic communities in semiarid regions. As this effect was quite pronounced in this study, a conventional RDA would mask the spatial effect on the community.

For all tests, the significance level was set at 0.05 . Analyses were performed in BiodiversityR packages (Kindt \& Coe, 2005) and Vegan (Oksanen et al., 2015), using the R.2.3.0 program (R Development Core Team, 2015).

\section{Results}

Accumulated precipitation was $1,119.4 \mathrm{~mm}$ in 2013 and $878.7 \mathrm{~mm}$ in 2014. During the collection months, the largest rainfall volume (Figure 2) was recorded in January 2014 and the lowest in September/2014. 
In September 2013, the highest values of dissolved oxygen and transparency were recorded, while in September 2014, the reservoir showed the highest chlorophyll-a values and electric conductivity levels (Table 2). In January 2014, total suspended solids and its fractions, turbidity, and temperature were highest.

Limnological variables differed significantly among the sampled months (PERMANOVA, Pseudo-F $=19.51, \mathrm{p}=0.001)$, while there was no significant difference between compartments (PERMANOVA, Pseudo-F = 0.96; $\mathrm{p}=0.394$ ).

The first two axes of the PCA (Figure 3) explained $69.59 \%$ of the variance of the data:

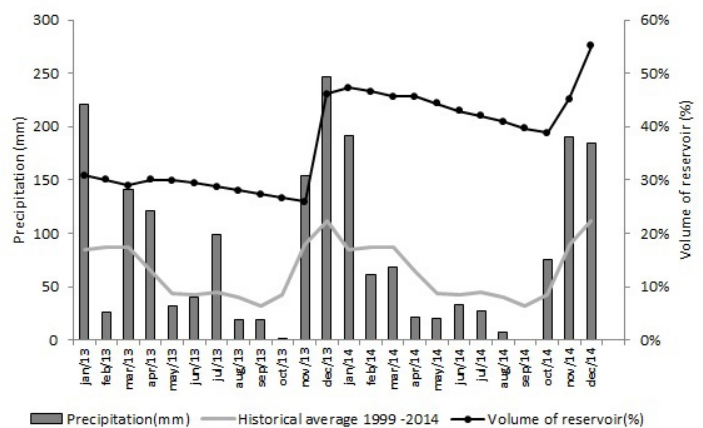

Figure 2. Cumulative rainfall in Jequié city, and volume in Barragem da Pedra reservoir between 2013 and 2014 years, and historical average precipitation. Source: Precipitation - Agritempo; Volume of reservoir - Agência Nacional de Águas (ANA, 2016).

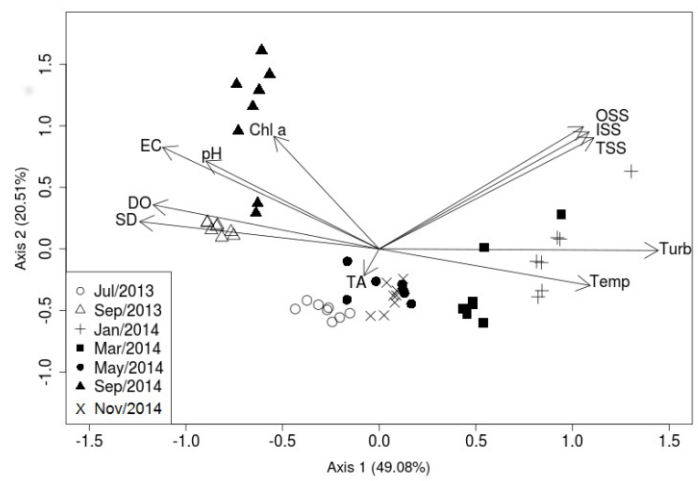

Figure 3. Biplot of principal component analysis (PCA) performed with the physical and chemical variables (EC: electrical conductivity; DO: dissolved oxygen; Turb: Turbidity; Temp: water temperature; OSS: suspended organic solids; TSS: suspended total solids; ISS: suspended inorganic solids; Chl a: chlorophyll- $a$; TA: total alkalinity; SD: Secchi disk), obtained between July 2013 and November 2014 of the reservoir Barragem da Pedra, Jequié, Bahia.
Axis 1 explained 49.08\% and Axis 2 explained $20.51 \%$. Axis 1 was negatively related with electrical conductivity, $\mathrm{pH}$, water transparency, and dissolved oxygen and positively with turbidity, temperature, total suspended solids, and organic and inorganic fractions. Axis 2 was positively related to chlorophyll- $a$ and negatively to alkalinity. The order of the sites sampled reflected the similarity between the months, indicating the greater influence of temporal variation on limnological characteristics in relation to spatial variation.

Ten microcrustacean species was recorded (Table 3): four cladocera and six copepoda. Macrocyclops albidus (Jurine, 1820) occurred only in March 2014 in lateral compartment, Thermocyclops decipiens (Kiefer, 1929) only in July 2013 in central compartment. Ceriodaphnia cornuta (Sars, 1886) was only found in September and November 2014, Diaphanosoma spinulosum (Herbst, 1967) occurred in July 2013, September 2013, and January 2014, while the occurrence of Daphnia gessneri (Herbst, 1967) was not recorded in November 2014. Diaphanosoma birgei (Korineck, 1981) as well as the three species of copepods (Calanoida) recorded in this study occurred in all samplings. With the exception of Macrocyclops albidus and Thermocyclops decipiens the other species occurred in both compartments.

In the central compartment (Figure 4) the lowest average values of species richness and abundance were recorded $\left(S=4.25 ; 0.9\right.$ ind. $\mathrm{L}^{-1}$, respectively) and the highest average value of evenness $(\mathrm{J}=0.81)$. All community metrics showed significant differences between the compartments, namely species richness (ANOVA repeated measures $\mathrm{F}=7.76, \mathrm{p}<0.001$; lateral compartment $>$ central compartment), abundance (ANOVA repeated measures $\mathrm{F}=19.92, \mathrm{p}<0.001$; lateral compartment $>$ central compartment) and Evenness (ANOVA repeated measures $\mathrm{F}=17.74, \mathrm{p}<0.001$; lateral compartment < central compartment). The PERMANOVA (Table 4) performed to verify the temporal and spatial variation of the microcrustacean assemblage indicated that the community differed significantly among months $(\mathrm{p}=0.001)$ and between compartments $(\mathrm{p}=0.001)$. However, we did not observe a significant interaction between months and compartments.

The results obtained by PERMANOVA were evidenced by NMDS. In the temporal variation, the sample units of September and July 2013 and November 2014 tended to stay in the left region of Figure 5a, while samples from January 


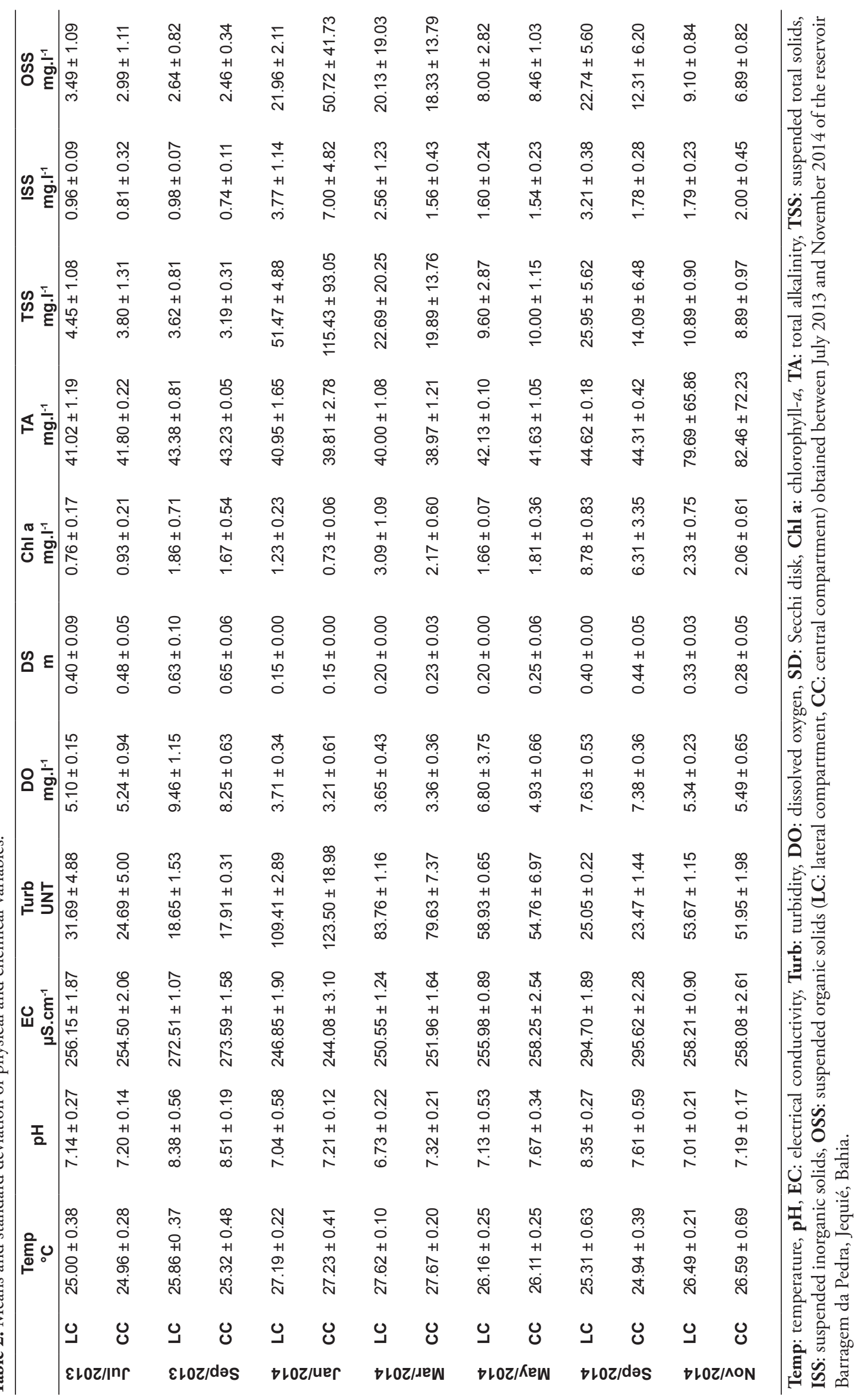



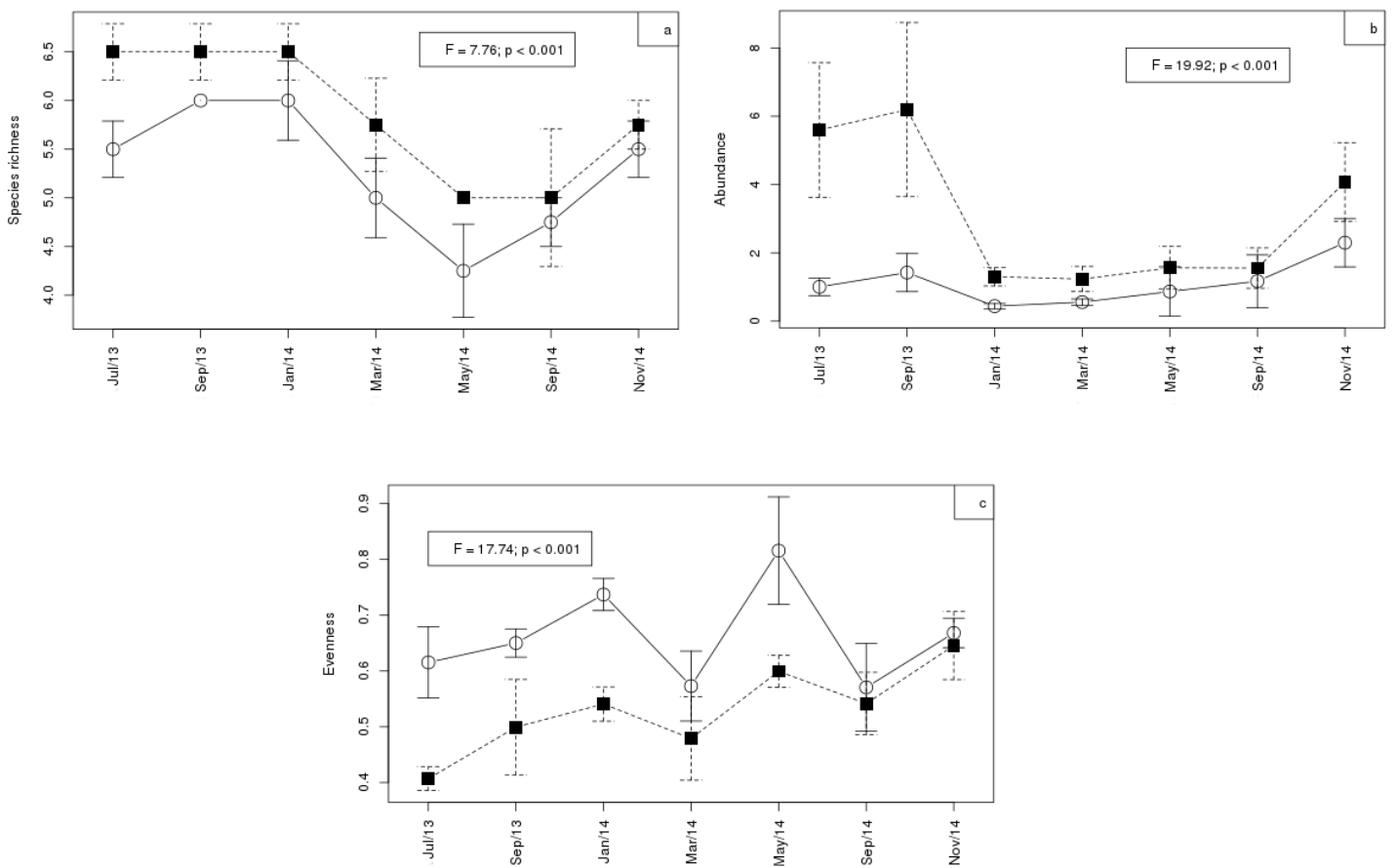

Figure 4. Average richness (a), abundance (b) and evenness (c) of microcrustacean assemblage (vertical bars: standard error) per month sampled ( $\mathrm{O}=$ central compartment, $\mathbf{\|}=$ lateral compartment) of the reservoir Barragem da Pedra, Jequié, Bahia.
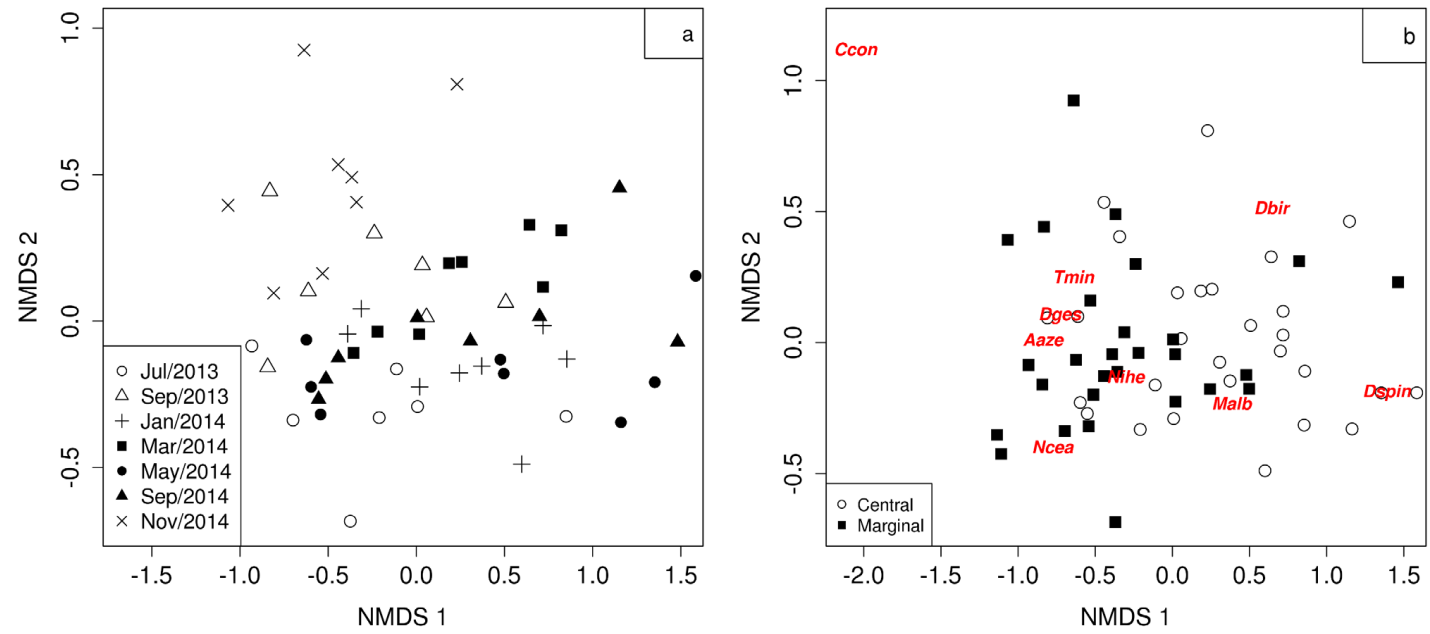

Figure 5. Non-metric multidimensional scaling (NMDS) based on the temporal (a) and spatial (b) variation of the microcrustacean assemblages structure between July 2013 and November 2014 of the reservoir Barragem da Pedra, Jequié, Bahia. O July/2013; $\triangle$ September/2013; + January/2014; - March/2014; • May/2014; $\triangle$ September/2014; $\times$ November/2014.

to September 2014 were arranged in the region across the right side of the figure. Regarding spatial variation, it was noted that the sampling units belonging to the lateral compartment are more located in the left hand side of Figure $5 \mathrm{~b}$ while the sample units of the central compartment are arranged in a reverse order, indicating a difference in microcrustacean assembly structure between compartments. Copepods (A. azevedoi, M. albidus, $N$. cearensis, $N$. iheringi and $T$. minutus) and cladocerans (C. cornuta and D. gessneri) were predominant in the lateral compartment, while the 
Table 3. List of species of cladocerans and copepods occurring in the period between July 2013 and November 2014 of the reservoir Barragem da Pedra, Jequié, Bahia.

\begin{tabular}{cc}
\hline Cladocera & Specie \\
\hline & Daphnia gessneri Herbst, 1967 \\
& Diaphanosoma birgei Korineck, 1981 \\
Copepoda Calanoida & Diaphanosoma spinulosum Herbst, 1967 \\
& Ceriodaphnia cornuta Sars, 1886 \\
& Argyrodiaptomus azevedoi Wright, 1935 \\
Copepoda Cyclopoida & Notodiaptomus cearensis Wright, 1936 \\
& Notodiaptomus iheringi Wright, 1935 \\
& Macrocyclops albidus Jurine, 1820 \\
& Thermocyclops minutus Lowndes, 1934 \\
& Thermocyclops decipiens Kiefer, 1929 \\
\hline
\end{tabular}

Table 4. PERMANOVA of the months and compartments sampled in relation to abundance and species composition of microcrustaceans in the reservoir Barragem da Pedra, Jequié.

\begin{tabular}{cccc}
\hline Variable & $\mathbf{R}^{2}$ & Pseudo- $\boldsymbol{F}$ & $\boldsymbol{p}$ \\
\hline Months & 0.30 & 4.34 & $\mathbf{0 . 0 0 1}$ \\
Compartments & 0.11 & 9.46 & $\mathbf{0 . 0 0 1}$ \\
Months: compartments & 0.09 & 1.34 & $\mathbf{0 . 1 5 8}$ \\
\hline
\end{tabular}

copepod T. decipiens and the cladocerans $D$. birgei and D. spinulosum were most representative in the central compartment (Figure 5b).

Partial redundancy analysis (pRDA), removing the effect of temporal variation, explained $11 \%$ ( $\mathrm{R}^{2}$ adjusted) of the spatial variation of microcrustacean assembly (ANOVA, Pseudo-F $=2.08 ; \mathrm{p}=0.001$ ). The first two axes of the analysis accounted for $16 \%$ of data variability, $10 \%$ referring to the axis 1 and $6 \%$ to the axis 2 (Figure 6). For axis 1, it was not possible to observe a clear pattern of ordering, but in axis 2, the multivariate gradient was characterized by a negative correlation with temperature and a positive correlation with chlorophyll-a, $\mathrm{pH}$, and alkalinity; these variables were more associated with the lateral compartment. However, although significant, the explanation for the spatial variation of the limnological variables was very low. Thus, it is likely that the limnological variables are not related to the compartmentalized distribution of microcrustaceans.

The abundance of Cyclopoida nauplii (Mann-Whitney; $\mathrm{w}=228 ; \mathrm{p}=0.007$ ), nauplii of Calanoida (Mann-Whitney; $w=239$, $\mathrm{p}=0.01$ ), Cyclopoida copepodids (Mann-Whitney; $\mathrm{w}=124 ; \mathrm{p}=0.01)$, and Calanoida copepodids (Mann-Whitney; $\mathrm{w}=116, \mathrm{p}=0.01$ ) differed significantly among the sampled compartments.

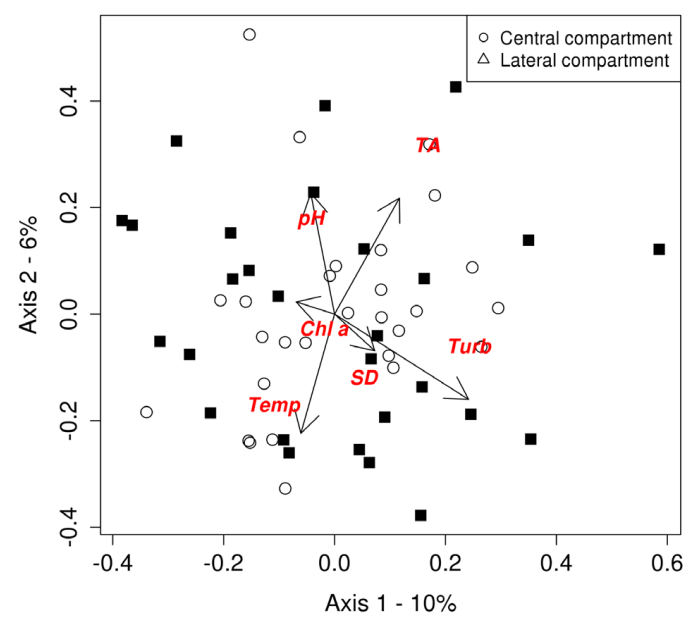

Figure 6. Ordination scatter plot (pRDA) generated from six abiotic variables (Turb: turbidity; SD: Secchi disk; TA: total alkalinity; Chl a: chlorophyll-a; Temp: temperature, $\mathrm{pH}$ ) and abundance of sampled microcrustaceans between July 2013 and November 2014 of the reservoir Barragem da Pedra, Jequié, Bahia.

For all observed young forms (Figure 7), the highest abundance values occurred in the lateral compartment.

\section{Discussion}

Microcrustacean assemblages showed temporal and spatial changes, and was associated to the environmental variation, such as predicted in this study. In the temporal dynamics, strong limnological variation determined the temporal dynamics of the assembly. In space, besides the physical and chemical importance of waters, environmental factors, such as environmental structural complexity, provided by aquatic macrophytes, could be the main reason to variation of the zooplankton assemblage.

The highest values of turbidity and suspended material and their fractions were recorded in 

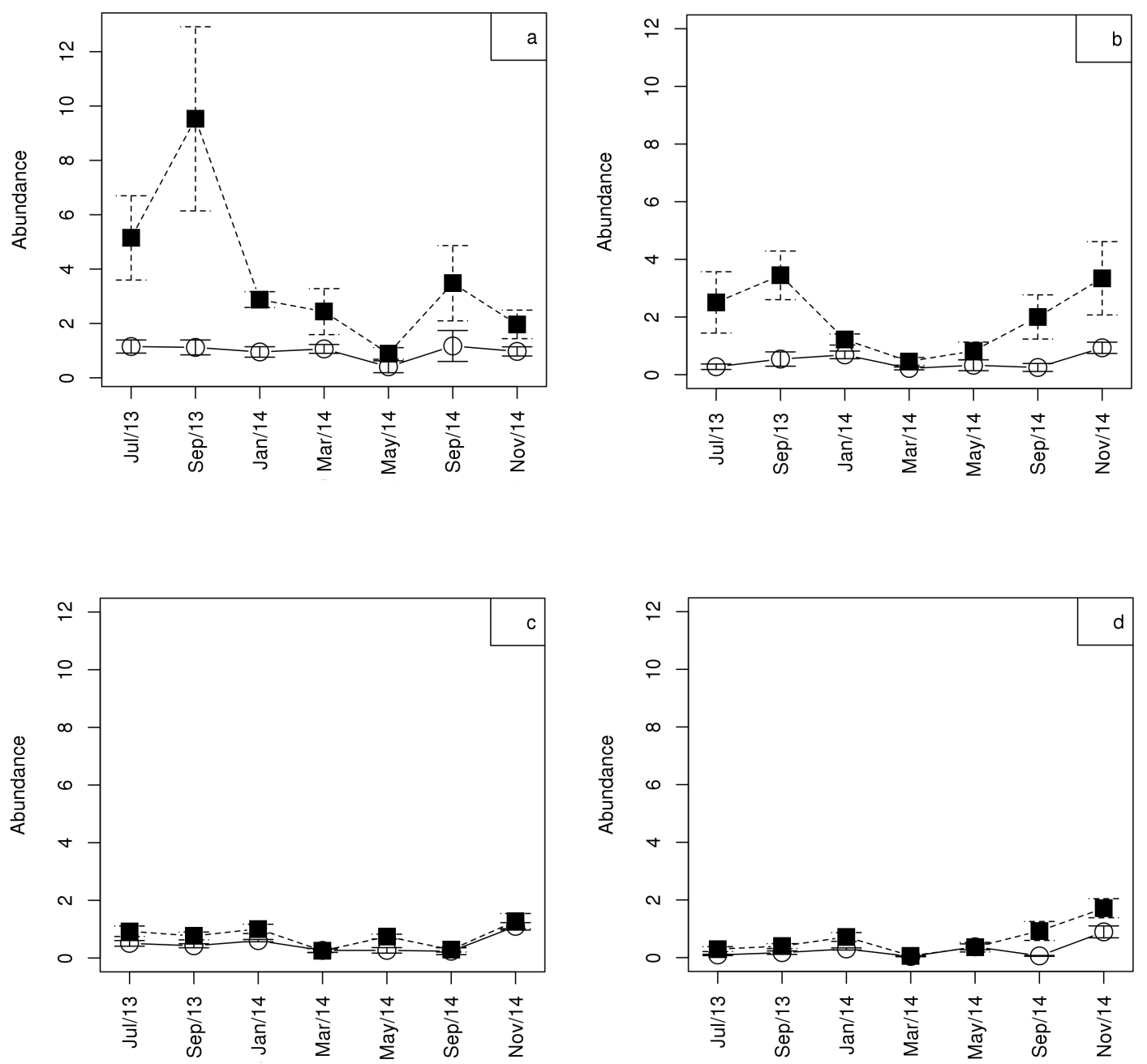

Figure 7. Average abundance of Calanoida copepodids (a), Cyclopoida copepodids (b), Calanoida nauplii (c) and Cyclopoida nauplii $(\mathbf{d})$ (vertical bars: standard error) per month sampled ( $\mathrm{O}=$ central compartment, $\mathbf{\square}=$ lateral compartment) of the reservoir Barragem da Pedra, Jequié, Bahia.

january/2014, when it was recorded highest precipitation during the study $(190.00 \mathrm{~mm})$. On the other hand, in the months of september 2013/2014 the precipitation volumes were lower and the reservoir presented the highest values of dissolved oxygen, electrical conductivity, chlorophyll-a and transparency of water. According to Bouvy et al. (2000), the physical and chemical water characteristics and the longitudinal gradients of the reservoirs, in semi-arid region, are affected by water balance. Rainfall promotes particle entrainment into the reservoir, increasing levels of solids in the suspension, causing an increase in turbidity and reduced light penetration and primary production (Baxter, 1977), while in the drought the evaporation promotes ions concentration. Limnological variables differed significantly between the sampling months, such as recorded in other studies performed in semiarid regions (Leitão et al., 2006; Sousa et al., 2008; Simôes \& Sonoda, 2009).

The spatial compartmentalization of the reservoir is a key issue from the point of view of management and multiple uses of water resources, as it gives subsidy to the selection of habitats more suitable for establishment of anthropic activities. Matsumura-Tundisi \& Tundisi (2005) point out that in studies on reservoirs, it is important to sample in both regions as spatial heterogeneity directly affects the abundance and richness of zooplankton.

Highest average species richness and abundance were recorded in the lateral compartment where it was observed the presence of aquatic macrophytes. 
Studies indicate that these plants support an abundant and diverse fauna of planktonic invertebrates, contributing to the increase in species richness due to the heterogeneity of habitat, resource supply, and high variability of physical and chemical characteristics (Van Den Brink et al., 1994; Burdis \& Hoxmeier, 2011; Colares et al., 2013) which cause spatial differences in primary and secondary productivity of reservoirs (Rocha et al., 1995) and serve as a "biological filter" due to their nutrient retention function (Nogueira \& Matsumura-Tundisi, 1996).

Moreover, although the central compartment presented lower mean abundance and diversity, it showed greater evenness, indicating a more uniform distribution of the microcrustacean assembly in this region. According to Bini et al. (1997), the distribution of zooplankton in aquatic ecosystems is not only influenced by the physical and chemical variables, but by behavior patterns and interspecific relationships are also factors that can explain the distribution. Thus, it is probably that the central compartments offers higher community organization and niches overlap and the competition can be an important interaction for this assemblage. Several studies have shown that the zooplankton community structure is strongly controlled by biotic factors such as predation and competition (Brooks \& Dodson, 1965; Dodson, 1974; Neill, 1975).

According to Bonecker et al. (2001), food availability (chlorophyll-a) is closely related to the abundance of calanoids. This study recorded that four species of Calanoida were most representative in the lateral compartment. As noted in this study, the prevalence of Calanoida juveniles in reservoirs is common and has been reported in other studies (Takahashi et al., 2009). According to Espíndola et al. (2000), the high production of the early stages of copepods in reservoirs is an adaptive strategy to compensate the high mortality before reaching adulthood.

The structure of the microcrustacean community (abundance, richness and evenness) differed significantly over time and between the compartments, while the abiotic variables showed significant differences only between different months. This result suggests that aquatic macrophytes, present in the lateral compartment, play an important role in the spatial distribution of the microcrustacean assemblage. The aquatic vegetation forms the structural environment of a variety of invertebrates in many systems (Stansfield et al., 1997; Cazzanelli et al., 2008) and has a significant influence on zooplankton diversity, because exerts multiple effects on aquatic ecosystems, such as reduction suspension sediment, preservation of the physical stability of the coastal zone, reduction of erosion, concentration of nutrients and improvement of eutrophication symptoms such as water turbidity (Horppila $\&$ Nurminen, 2005; Estlander et al., 2009).

In natural environment, variation of the abundances of species does not occur randomly, but in response to interspecific interactions and changes in environmental variables (Tilman et al., 1998). Responses to environmental fluctuations have been the most commonly used factor to explain the dynamics of species variation. In the semi-arid, such environmental variations between dry an rainy season exceed the tolerance limit of very organisms being a stronger drivers of temporal turnover of assemblage. Chase (2007), in experiments in microcosms, found that the importance of stochastic and ecological effects depends on the severity of the ecological filter to which the environment is subjected. Chase (2007) simulated the drought in lakes and found that the severity of this biofilter increased the similarity of the community by reducing its diversity, because the species that survive are those that support the most severe conditions. Therefore, even though the diversity of species from one place can recover after a stochastic event, the regional diversity is compromised. Thus, the reservoir studied, which presented a reduced number of zooplankton species when compared to other reservoirs in the semiarid region (Leitão et al., 2006; Sousa et al., 2008; Almeida et al., 2009; Vieira et al., 2009; Medeiros et al., 2011), must be carefully managed and conservation policies to mitigate the effects of natural and anthropogenic disturbances, reducing the likelihood of a loss of community diversity.

In this study, the microcrustacean assembly presented temporal and spatial variation influenced by abiotic factors (limnological variables) and by biotic factors (aquatic macrophytes). Thus, temporal variation is an important effect on the dynamics of limnological factors and determines the temporal variation of the community, while the presence of macrophytes plays an important role in the spatial distribution of the microcrustacean assemblage.

\section{References}

AGÊNCIA NACIONAL DE ÁGUAS - ANA. Sistema de acompanhamento de reservatórios [online]. Brasília: ANA, 2016 [viewed 10 Mar. 2016]. Available from: http://sar.ana.gov.br/Medicao 
ALMEIDA, V.L.S., DANTAS, E.W., MELO-JÚNIOR, M., BITTENCOURT-OLIVEIRA, M.C. and MOURA, A.N. Zooplanktonic community of six reservoirs in northeast Brazil. Brazilian Journal of Biology = Revista Brasileira de Biologia, 2009, 69(1), 57-65. http://dx.doi.org/10.1590/S151969842009000100007. PMid:19347146.

BAXTER, R.M. Environmental effects of dams and impoundments. Annual Review of Ecology and Systematics, 1977, 8(1), 255-283. http://dx.doi. org/10.1146/annurev.es.08.110177.001351.

BERNOT, R.J., DODDS, W.K., QUIST, M.C. and GUY, C.S. Spatial and temporal variability of zooplankton in a great plains reservoir. Hydrobiologia, 2004, 525(1-3), 101-112. http://dx.doi.org/10.1023/ B:HYDR.0000038857.19342.fd.

BETSILL, R.K. and VAN DEN AVYLE, M.J. Spatial heterogeneity of reservoir zooplankton: a matter of timing? Hydrobiologia, 1994, 277(1), 63-70. http:// dx.doi.org/10.1007/BF00023986.

BINI, L.M., TUNDISI, J.G., MATSUMURATUNDISI, T. and MATHEUS, C.E. Spatial variation of zooplankton groups in a tropical reservoir (Broa Reservoir, Sao Paulo State-Brazil). Hydrobiologia, 1997, 357(1-3), 89-98. http://dx.doi. org/10.1023/A:1003178618304.

BONECKER, C.C., LANSAC-TÔHA, F.A., VELHO, L.F.M. and ROSSA, D.C. The temporal distribution patter of Copepods in Corumbá Reservoir, State of Goias, Brazil. Hydrobiologia, 2001, 453-454 (1), 375384. http://dx.doi.org/10.1023/A:1013142101266.

BOUVY, M., FALCÃO, D., MARINHO, M., PAGANO, M. and MOURA, A. Occurrence of Cylindrospermopsis (Cyanobacteria) in 39 Brazilian tropical reservoirs during 1998. Aquatic Microbial Ecology, 2000, 23(1), 13-27. http://dx.doi. org/10.3354/ame023013.

BRITO, S.L., MAIA-BARBOSA, P.M. and PINTOCOELHO, R.M. Zooplankton as an indicator of trophic conditions in two large reservoirs in Brazil. Lakes and Reservoirs: Research and Management, 2011, 16(4), 253-264. http://dx.doi.org/10.1111/j.14401770.2011.00484.x.

BROOKS, J.L. and DODSON, S.I. Predation, body size, and composition of the plankton. Science, 1965, 150(3692), 28-35. http://dx.doi.org/10.1126/ science.150.3692.28. PMid:17829740.

BURDIS, R.M. and HOXMEIER, R.J.H. Seasonal zooplankton dynamics in main channel and backwater habitats of the Upper Mississippi River. Hydrobiologia, 2011, 667(1), 69-87. http://dx.doi. org/10.1007/s10750-011-0639-y.

CAZZANELLI, M., WARMING, T.P. and CHRISTOFFERSEN, K.S. Emergent and floatingleaved macrophytes as refuge for zooplankton in a eutrophic temperate lake without submerged vegetation. Hydrobiologia, 2008, 605(1), 113-122. http://dx.doi.org/10.1007/s10750-008-9324-1.

CHASE, J.M. Drought mediates the importance of stochastic community assembly. Proceedings of the National Academy of Sciences of the United States of America, 2007, 104(44), 17430-17434. http://dx.doi. org/10.1073/pnas.0704350104. PMid:17942690.

COLARES, M.A.M., BONECKER, C.C., SIMÓES, N.R., ALVES, G.M. and LANSAC-TÔHA, F.A. Structure of the zooplankton communities in macrophytes stand of a Neotropical floodplain (the Paraná River, Brazil). International Review of Hydrobiology, 2013, 98(2), 89-103. http://dx.doi. org/10.1002/iroh.201301471.

DODSON, S.I. Zooplankton competition and predation: an experimental test of the size-efficiency hypothesis. Ecology, 1974, 55(3), 605-613. http:// dx.doi.org/10.2307/1935150.

ELMOOR-LOUREIRO, M.A.L. Manual de identificação de cladóceros límnicos do Brasil. Brasília: Universo, 1997.

ESPÍNDOLA, E.L.G., MATSUMURA-TUNDISI, T., RIETZLER, A.C. and TUNDISI, J.G. Spatial heterogeneity of the Tucuruí reservoir (State of Pará, Amazonia, Brazil) and the distribution of zooplankton species. Revista Brasileira de Biologia, 2000, 60(2), 179-194. http://dx.doi.org/10.1590/ S0034-71082000000200001. PMid:10959101.

ESTLANDER, S., NURMINEN, L., OLIN, M., VINNI, M. and HORPPILA, J. Seasonal fluctuations in macrophyte cover and water transparency of four brown-water lakes: implications for crustacean zooplankton in littoral and pelagic habitats. Hydrobiologia, 2009, 620(1), 109-120. http://dx.doi. org/10.1007/s10750-008-9621-8.

GOLTERMAN, H.L., CLYMO, R.S. and OHSTAD, M.A. Methods for physical \& chemical analysis of freshwater. 2nd ed. Oxford: Blackwell Scientific Publications, 1978, $231 \mathrm{p}$.

HORPPILA, J. and NURMINEN, L. Effects of different macrophyte growth forms on sediment and $\mathrm{P}$ resuspension in a shallow lake. Hidrobiologia, 2005, 545(1), 167-175. http://dx.doi.org/10.1007/ s10750-005-2677-9.

INSTITUTO BRASILEIRO DE GEOGRAFIA E ESTATÍSTICA - IBGE. Cidades [online]. Rio de Janeiro: IBGE, 2016 [viewed 10 Mar. 2016]. Available from: https://cidades.ibge.gov.br/

JUNK, W.J. and ROBERTSON, B.A. Aquatic Invertebrates. In: W.J. JUNK, ed. The central amazona floodplain: ecology of a pulsing system. Berlin: Springer, 1997, pp. 279-298. Ecological Studies Series, vol. 216. http://dx.doi.org/10.1007/978-3-662-034163_13.

KIMMEL, B.L., LIND, O.T. and PAULSON, L.J. Reservoir primary production. In: K.W. 
THORNTON, B.L. KIMMEL and F.E. PAYNE, eds. Reservoir limnology: ecological perspectives. New York: Wiley Interscience Publication, 1990, pp. 133-193.

KINDT, R. and COE, R. Tree diversity analysis: a manual and software for common statistical methods for ecological and biodiversity studies. Nairobi: World Agroforestry Centre (ICRAF), 2005.

KREBS, C.J. Ecological methodology. 2nd ed. New York: Benjamin Cummings, 1998.

LEGENDRE, P. and LEGENDRE, L. Numerical ecology. Amsterdam: Elsevier Science, 1998, 853 p.

LEITÃO, A.C., FREIRE, R.H.F., ROCHA, O. and SANTAELLA, S.T. Zooplankton community composition and abundance of two Brazilian semiarid reservoirs. Acta Limnologica Brasiliensia, 2006, 18, 451-468.

MACKERETH, F.I.H., HERON, J. and TALLING, J.F. Water analysis: some revised methods for limnologists. London: Freshwater Biological Association, 1978, $121 \mathrm{p}$.

MAGURRAN, A. E. Medindo a diversidade biológica. Curitiba: Ed. UFPR, 2013.

MARZOLF, G.R. Reservoirs as environments for zooplankton. In: K.W. THORNTON, B.L. KIMMEL and F.E. PAYNE, eds. Reservoir limnology: ecological perspectives. New York: John Wiley \& Sons, 1990, pp. 195-208. chap. 7.

MATSUMURA-TUNDISI, T. and TUNDISI, J.G. Plankton richness in a eutrophic reservoir (Barra Bonita Reservoir, SP, Brazil). Hydrobiologia, 2005, 542(1), 367-378. http://dx.doi.org/10.1007/s10750004-9461-0.

MATSUMURA-TUNDISI, T. Latitudinal distribution of Calanoida copepods in freshwater aquatic systems of Brazil. Revista Brasileira de Biologia, 1986, 46, 527-553.

MEDEIROS, E.S.F., NOIA, N.P., ANTUNES, L.C. and MELO, T.X. Zooplankton composition in aquatic systems of semi-arid Brazil: Spatial variation and implications of water management. Pan-American Journal of Aquatic Sciences, 2011, 6(4), 290-302.

NEILL, W.E. Experimental studies of microcrustacean copetition, community composition and efficience of resource utilization. Ecology, 1975, 56(4), 809-826. http://dx.doi.org/10.2307/1936293.

NEWEL, G. E. and NEWEL, R.C. Marine plankton. London: Hutchinson Educational Great, 1963

NOGUEIRA, M.G. and MATSUMURA-TUNDISI, T. Limnologia de um sistema artificial (Represa Monjolinho - São Carlos, SP). Dinâmica das populaçóes planctônicas. Acta Limnologica Brasiliensia, 1996, 8(1), 149-168.

NOGUEIRA, M.G. Zooplankton composition, dominance and abundance as indicators of environmental compartmentalization in jurumirim reservoir (Paranapanema river), São Paulo, Brazil. Hydrobiologia, 2001, 455(1/3), 1-18. http://dx.doi. org/10.1023/A:1011946708757.

OKSANEN, J., BLANCHET, F.G., KINDT, R., LEGENDRE, P., MINCHIN, P.R., O'HARA, R.B., SIMPSON, G.L., SOLYMONS, P., HENRY, M., STEVENS, H. and WAGNER, H. Vegan: Community Ecology Package. R package version 2.3$O$ [software]. Vienna: R Foundation for Statistical Computing, 2015 [viewed 25 Nov. 2016]. Available from: http://cran.r-project.org/web/packages/vegan/ index.html

PANARELLI, E., CASANOVA, S.M.C., NOGUEIRA, M.G., MITSUKA, P.M. and HENRY, R. A comunidade zooplanctônica ao longo de gradientes longitudinais no Rio Paranapanema/ Represa de Jurumirim (São Paulo, Brasil). In: R. HENRY, ed. Ecótonos nas interfaces dos ecossistemas aquáticos. São Paulo: Rima, 2003, pp. 131-162.

PERBICHE-NEVES, G. and NOGUEIRA, M.G. Reservoir design and operation: effects on aquatic biota: a case study of planktonic copepods. Hydrobiologia, 2013, 707(1), 187-198. http://dx.doi. org/10.1007/s10750-012-1425-1.

PINEL-ALLOUL, B. and MIMOUNI, E.A. Are cladoceran diversity and community structure linked to spatial heterogeneity in urban landscapes and pond environments? Hydrobiologia, 2013, 715(1), 195212. http://dx.doi.org/10.1007/s10750-013-1484-y.

PINTO-COELHO, R., PINEL-ALLOUL, B., MÉTHOT, G. and HAVENS, K.E. Crustacean zooplankton in lakes and reservoir of temperate and tropical regions: variation with trophic status. Canadian Journal of Fisheries and Aquatic Sciences, 2005, 62(2), 348-361. http://dx.doi.org/10.1139/ f04-178.

R DEVELOPMENT CORE TEAM. $R$ : a language and environment for statistical computing. Vienna: $\mathrm{R}$ Foundation for Statistical Computing, 2015.

REID, J.W. Chave de identificação e lista de referências bibliográficas para as espécies continentais sulamericanas de vida livre da ordem Cyclopoida (Crustacea, Copepoda). Boletim de Zoologia, 1985, 9, 17. http://dx.doi.org/10.11606/issn.2526-3358. bolzoo.1985.122293.

ROCHA, O., DENDACZ, S. and MATSUMURATUNDISI, T. Composition biomass and productivity of zooplankton in natural lakes and reservoirs of Brazil. In: J.G. TUNDISI, C.E.M. BICUDO and E. MATSUMURA-TUNDISI, eds. Limnology in Brazil. Rio de Janeiro: ABC/SBL, 1995, pp. 151-166.

ROCHA, O., MATSUMURA-TUNDISI, T., ESPÍNDOLA, E.L.G., ROCHE, K.F. and RIETZLER, A.C. Ecological theory applied to reservoir zooplankton. In: J.G. TUNDISI and M. STRASKRABA, eds. Theoretical reservoir ecology and 
its applications. Sáo Carlos: Instituto Internacional de Ecologia, 1999, pp. 457-576.

SIMÕES, N. and SONODA, S.L. Estrutura da assembléia de microcrustáceos (Cladocera e Copepoda) em um reservatório do semi-árido Neotropical, Barragem de Pedra, Estado da Bahia, Brasil. Acta Scientiarum. Biological Sciences, 2009, 31(1), 89-95. http://dx.doi. org/10.4025/actascibiolsci.v31i1.538.

SIMÓES, N.R., NUNES, A.H., DIAS, J.D., LANSACTOHA, F.A., VELHO, L.F.M. and BONECKER, C.C. Impact of reservoirs on zooplankton diversity and implications for the conservation of natural aquatic environments. Hydrobiologia, 2015, 758(1), 3-17. http://dx.doi.org/10.1007/s10750-0152260-y.

SOUSA, W., ATTAYDE, J.L., ROCHA, E.D.S. and ESKINAZI-SANT'ANNA, E.M. The response of zooplankton assemblages to variations in the water quality of four man-made lakes in semi-arid northeastern Brazil. Journal of Plankton Research, 2008, 30(6), 699-708. http://dx.doi.org/10.1093/ plankt/fbn032.

STANSFIELD, J.H., PERROW, M.R., TENCH, L.D., JOWITT, A.J.D. and TAYLOR, A.A.L. Submerged macrophytes as refuges for grazing Cladocera against fish predation: observations on seasonal changes in relation to macrophyte cover and predation pressure. Hydrobiologia, 1997, 342/343, 229-240. http:// dx.doi.org/10.1023/A:1017091407556.

TAKAHASHI, E.M., LANSAC-TÔHA, F.A., DIAS, J.D., BONECKER, C.C. and VELHO, L.F.M. Spatial variations in the zooplankton community from the Corumbá Reservoir, Goias State, in distinct hydrological periods. Acta Scientiarum. Biological Sciences, 2009, 31, 227-234.

TEIXEIRA, C. and KUTNER, M.M. Plankton studies in a mangrove environment: I first assessment of standing stock and principal ecological factors. Boletim do Instituto Oceanográfico, 1962, 12(3), 101 -124. http://dx.doi.org/10.1590/S037355241962000300006.

THORNTON, J.A. and RAST, W. A test of hypotheses relating to the comparative limnology and assessment of eutrophication in semi-arid man-made lakes. In: Y. STRASKRABA, J.G.A. TUNDISI and A. DUNCAN, eds. Comparative reservoir limnology and water quality management. London: Kluwer Academic Publishers, 1993, pp. 1-24. http://dx.doi. org/10.1007/978-94-017-1096-1_1.

TILMAN, D., LEHMAN, C. and BRISTOW, C. Diversity-stability relationships: statistical inevitability or ecological consequence? American Naturalist, 1998, 151(3), 277-282. http://dx.doi. org/10.1086/286118. PMid:18811358.

TUNDISI, J.G. Gerenciamento integrado de bacias hidrográficas e reservatórios: estudos de caso e perspectivas. In: M.G. NOGUEIRA, R. HENRY and A. JORCIN, eds. Ecologia de reservatórios. 2nd ed. São Carlos: Rima, 2006, pp. 1-21.

VAN DEN BRINK, F.W.B., VAN KATWIJK, M.M. and VAN DER VELDE, G. Impact of hydrology on phyto and zooplankton communities composition in floodplain lakes along the Lower Rhine and Meuse. Journal of Plankton Research, 1994, 16(4), 351-373. http://dx.doi.org/10.1093/plankt/16.4.351.

VIEIRA, A.C.B., RIBEIRO, L.L., SANTOS, D.P.N. and CRISPIM, M.C. Correlation between the zooplanktonic community and environmental variables in a reservoir from the Northeastern semiarid. Acta Limnologica Brasiliensia, 2009, 21(3), 349-358.

Received: 25 November 2016 Accepted: 15 January 2018 